\title{
Occurrence and activity of American martens Martes americana in relation to roads and other routes
}

\author{
Jean-François ROBITAILLE and Karl AUBRY
}

\begin{abstract}
Robitaille J.-F. and Aubry K. 2000. Occurrence and activity of American martens Martes americana in relation to roads and other routes. Acta Theriologica 45: 137-143.

In order to clarify the relationship between American martens Martes americana (Turton, 1806), and roads in boreal forests, we tested the effect of distance from road on marten habitat use by comparing the frequency of occurrence, and the number of, marten snow tracks in 27 pairs of 300 and $400 \mathrm{~m}$ transect segments perpendicular to access roads, and corresponding segments 800 or $1000 \mathrm{~m}$ away from the road, for a total of four spatial analyses. The number of black spruce Picea mariana, stems was generally lower near roads $\left(-94.0<\mathrm{T}_{\mathrm{s}}<-63.0, p<0.05\right)$, but otherwise forest composition generally did not differ significantly between road and forest segments. Depending on the spatial scale, 11 - 14 road and 15 - 18 forest (out of 27) segments had marten tracks, but the difference was not statistically significant (Fisher's exact test, $p>0.05$ ). In all analyses, marten tracks were significantly fewer near roads (Wilcoxon test: $\left.-74.0<\mathrm{T}_{\mathrm{s}}<-62.0, p<0.01\right)$ than away from roads. In segments with tracks, track density was significantly lower near roads than away from roads in three of four spatial analyses $\left(-3.3<\mathrm{T}_{\mathrm{s}}<-2.9, p<0.01\right)$. The findings suggest that snow track samples near roads can detect marten occurrence, but do not reflect the clumping pattern observed away from roads. Habitat selection studies using tracks should consider the possible effect of roads on marten movement patterns.
\end{abstract}

Department of Biology, Laurentian University, Sudbury, Ontario, Canada P3E 2C6, e-mail: robitail@nickel.laurentian.ca

Key words: Martes americana, edge effect, habitat use, snowtracking

\section{Introduction}

With growing interest in the conservation of biodiversity in man-modified environments, effect of edges in heterogeneous habitats has been the focus of several recent ecological studies (Jokimäki and Huhta 1996, Garcia et al. 1998, Gardner 1998, Hansson 1998, Kuitunen et al. 1998, Stevens and Husband 1998). Knowledge of edge effects aid management authorities in planning timber harvest and wildlife conservation (Darveau et al. 1997), in particular indicator species (Niemi et al. 1997) such as the marten in northern Ontario (Watt et al. 1996). Martens are known to avoid open areas, but evidence for their use or avoidance of edges is somewhat contradictory. Buskirk and Powell (1994) hypothesized that edge preference or avoidance by martens is a function of particular habitat values within the edge. Martens also are known to use marginally suitable forested areas 
as travel corridors (Potvin and Breton 1997). Evidence of how martens use forest edges habitats is scarce and no study has yet considered marten movement patterns specifically in relation to road corridors. Yet, it is not uncommon to find marten habitat studies where sampling occurred in proximity of a road system.

The objective of this study was to examine the effect of road proximity on the movement patterns of martens. Here we compare the occurrence (presence-absence) of marten tracks and the number of marten tracks near and away from active access routes (including seasonal snowmobile trails) in northern Ontario boreal forest. Because of the low road density of roads and trails and relatively low traffic in northern boreal forest, we predicted that marten track distribution near roads would not differ from that found in core of the forest matrix.

\section{Material and methods}

The study site was an $1,100-\mathrm{km}^{2}$ area south of Timmins ( $48^{\circ} 30^{\prime} \mathrm{N}, 81^{\circ} 00^{\prime} \mathrm{W}$; Fig. 1 ) where U-shaped transects (Fig. 1 inset) were sampled for vegetation and marten tracks during February and March 1994. For the purpose of the present study, a sub-sample of twenty-seven transects averaging $2.4 \mathrm{~km}$ (range 1.9-3.1 km) in length were selected that were large enough to include a forest transect, that were at least $1 \mathrm{~km}$ away from the nearest transect, and where vegetation survey was available. Chosen transects were located off six of 10 logging roads, two hydro-electric power lines, and proxincial highway 144, where widths varied approximately between $20 \mathrm{~m}$ and $50 \mathrm{~m}$. Logging roads remair open and active throughout the year (mostly commercial hauling during working days) while power lines are used as seasonal snowmobile trails and all-terrain vehicles for recreational and other (eg trapping) purposes. Forest attributes were measured in $10 \mathrm{~m}$ radius plots every $100 \mathrm{~m}$ along a segment. Forest cover characteristics included total stand height (ie summation of highest height in each plot) and the number of stems of black spruce Picea mariana, white spruce $P$. glauca, balsam fir Abies balsamea, jack pine Pinus banksiana, eastern cedar Thuja occidentalis, all conifers, poplar (Populus spp.), birch (Betula spp.) and all deciduous trees that fit a BAF2 prism (Grenier and Du Sablon 1993). Structural characteristics included number of stumps, fallen logs $>10 \mathrm{~cm}$ diameter at breast height (DBH), and other structures (eg boulders). Differences in the number of marten tracks and tree stems between pairs of road and forest 300- and 400-m transect segments were tested using Wilcoxon signed-rark test (hereafter $\mathrm{T}_{\mathrm{s}}$ ) with JMP 3.0. (SAS 1995). Road and forest segments were extracted from the original transect, hence pairs of road and forest segments were sampled on the same day. Segment lengths were chosen at 300 and $400 \mathrm{~m}$ to reflect reasonable portions of marten home range sizes, to mirimize zero values in samples, and to reduce the effect of recent logging near roads. We chose to teit two different road-forest intervals: $800 \mathrm{~m}$ or $1000 \mathrm{~m}$. Four length/interval segment combinations were thus tested: (a) $300 \mathrm{~m}$ long / $800 \mathrm{~m}$ interval; (b) $300 \mathrm{~m}$ long / $1000 \mathrm{~m}$ interval; (c) $400 \mathrm{~m}$ long / $800 \mathrm{~m}$ interval and (d) $400 \mathrm{~m}$ long / $1000 \mathrm{~m}$ interval (hereafter 300/800, 300/1000, 400/800 and 400/1000 respectively). Differences in the frequency of occurrence of marten tracks in road vs. forest segments were tested using Fisher's exact test.

\section{Results}

Most analyses (ie segment length-interval combinations) indicated that forest cover near roads did not differ from that found away from roads. Black spruce were significantly fewer near roads at three levels of analysis $\left(-94.0<\mathrm{T}_{\mathrm{s}}<-63.0 p<\right.$ $0.05)$, but the number of conifer stems were not. Deciduous trees were significantly 

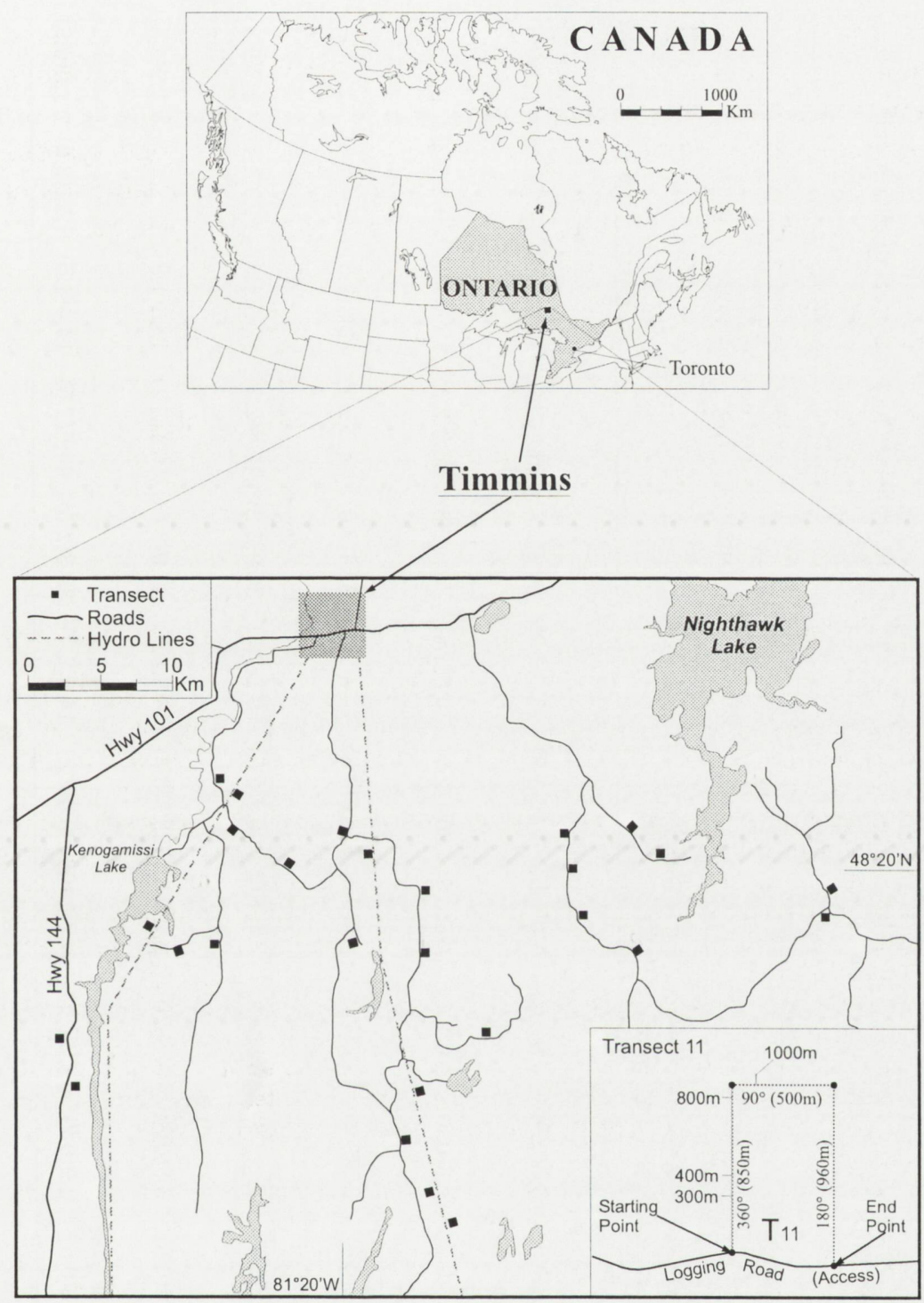

Fig. 1. Layout of logging roads, hydro-electric power lines and 27 snowtracking transects in a $1100 \mathrm{~km}^{2}$ a study area south of Timmins, Ontario. Inset: Bearings, distances and intervals on Transect 11 .

fewer on road segments in one $(400 / 1000 \mathrm{~m}$ level $)$ analysis $\left(\mathrm{T}_{\mathrm{s}}=-77.0, p<0.05\right)$. There were no significant differences in the density of shrubs, stumps, logs and other structural characteristics between road and forest segments $\left(-62.0<\mathrm{T}_{\mathrm{s}}<\right.$ $49.5 ; p>0.05)$. Stand height was lower in the forest than on road segments only at the $300 / 800 \mathrm{~m}$ level $\left(\mathrm{T}_{\mathrm{s}}=-83.0, p<0.05\right)$ (Table 1$)$. 
Table 1. Average number of marten tracks and stems (> $10 \mathrm{~cm} \mathrm{DBH})( \pm 1 \mathrm{SE})$ of 300 and $400 \mathrm{~m}$ transects and intervals of $800 \mathrm{~m}$ and $1000 \mathrm{~m}$. Matching letters within column indicate significant differences.

\begin{tabular}{|c|c|c|c|c|c|c|c|c|c|c|c|c|c|}
\hline \multirow{3}{*}{$\begin{array}{l}\text { Treat- } \\
\text { ment }\end{array}$} & \multirow{3}{*}{$\begin{array}{l}\text { Marten } \\
\text { tracks }\end{array}$} & \multicolumn{8}{|c|}{ Number of stems } & \multirow{3}{*}{$\begin{array}{l}\text { Stand } \\
\text { height } \\
(\mathrm{m})\end{array}$} & \multicolumn{3}{|c|}{ Structure } \\
\hline & & \multicolumn{6}{|c|}{ Conifers } & \multirow{2}{*}{$\begin{array}{l}\text { Decid- } \\
\text { uous }\end{array}$} & \multirow[t]{2}{*}{ Total } & & \multirow[t]{2}{*}{ Stumps } & \multirow[t]{2}{*}{ Logs } & \multirow[t]{2}{*}{ Other } \\
\hline & & $\begin{array}{l}\text { Black } \\
\text { spruce }\end{array}$ & $\begin{array}{l}\text { White } \\
\text { spruce }\end{array}$ & $\begin{array}{l}\text { Balsam } \\
\text { fir }\end{array}$ & $\begin{array}{l}\text { Jack } \\
\text { pine }\end{array}$ & Cedar & Total & & & & & & \\
\hline \multicolumn{14}{|c|}{ Segment length $(300 \mathrm{~m})$} \\
\hline Road & $0.5(0.1)^{\mathrm{ab}}$ & $5.7(0.9)^{\mathrm{ab}}$ & $1.3(0.5)$ & $4.3(0.9)$ & $4.8(2.2)$ & $1.8(1.0)$ & $17.8(1.9)$ & $7.7(1.9)$ & $26.2(2.7)$ & $31.1(2.3)^{\mathrm{a}}$ & $10.0(1.2)$ & $7.7(1.0)$ & $1.1(0.8)$ \\
\hline \multicolumn{14}{|c|}{ Interval $(800 \mathrm{~m})$} \\
\hline Forest & $3.1(0.7)^{\mathrm{a}}$ & $11.7(2.2)^{\mathrm{a}}$ & $1.0(0.3)$ & $2.8(0.6)$ & $4.0(2.1)$ & $0.6(0.3)$ & $20.1(2.7)$ & $10.6(2.4)$ & $30.9(2.9)$ & $35.8(2.5)^{\mathrm{a}}$ & $12.8(1.5)$ & $9.2(1.3)$ & $0.8(0.7)$ \\
\hline \multicolumn{14}{|c|}{ Interval (1000 m) } \\
\hline Forest & $2.4(0.7)^{\mathrm{b}}$ & $11.5(2.2)^{b}$ & $1.2(0.4)$ & $2.7(0.6)$ & $2.4(1.2)$ & $2.0(0.6)$ & $19.9(2.6)$ & $11.4(2.4)$ & $31.4(3.0)$ & $34.3(2.2)$ & $12.3(1.5)$ & $9.0(1.4)$ & $1.4(0.6)$ \\
\hline \multicolumn{14}{|c|}{ Segment length $(400 \mathrm{~m})$} \\
\hline Road & $0.9(0.2)^{\mathrm{cd}}$ & $9.7(1.6)^{\mathrm{c}}$ & $1.7(0.7)$ & $5.1(1.0)$ & $6.6(2.9)$ & $3.7(1.6)$ & $26.8(2.5)$ & $9.5(2.3)^{\mathrm{a}}$ & $36.9(3.2)$ & $41.8(2.9)$ & 13.6(1.5) & $11.3(1.4)$ & $1.3(0.8)$ \\
\hline \multicolumn{14}{|c|}{ Interval $(800 \mathrm{~m})$} \\
\hline Forest & $3.3(0.8)^{\mathrm{c}}$ & $15.1(2.7)^{\mathrm{c}}$ & $1.5(0.5)$ & $3.8(0.8)$ & $3.7(2.0)$ & $2.1(0.6)$ & $26.3(3.3)$ & $14.6(3.1)$ & $41.0(3.6)$ & $46.1(3.2)$ & $15.6(1.8)$ & $12.2(1.7)$ & $1.7(0.8)$ \\
\hline \multicolumn{14}{|c|}{ Interval (1000 m) } \\
\hline Forest & $3.0(0.8)^{\mathrm{d}}$ & $11.7(1.8)$ & $1.8(0.5)$ & $4.0(0.8)$ & $3.2(1.7)$ & $4.3(1.6)$ & $25.0(2.2)$ & $14.0(2.4)^{\mathrm{a}}$ & $39.3(2.5)$ & $44.8(2.5)$ & $14.4(1.5)$ & $12.1(2.0)$ & $1.9(0.6)$ \\
\hline
\end{tabular}


The occurrence of marten tracks did not differ significantly between road segments and segments away from the roads $\left(-19.5<\mathrm{T}_{\mathrm{s}}<-9.0, p>0.05\right)$. At the $300 / 800$ and the $300 / 1000 \mathrm{~m}$ scale, 11 road and 18 forest segments had marten tracks. In the $400 \mathrm{~m}$ analysis, 14 road segments had marten tracks and 18 forest segments had tracks at $800 \mathrm{~m}$ spacing; at 1,000 m spacing, 15 forest segments had tracks. The consistently high number of segments without tracks throughout the sample suggested clumping of tracks.

At any scale of analysis, martens left on average significantly fewer tracks on road than on forest segments $\left(-74.0<\mathrm{T}_{\mathrm{s}}<-62.0, p<0.01\right.$; Table 1$)$. To further analyze clumping of tracks, track counts were compared among transects with tracks only. At the $300 \mathrm{~m}$ scale, martens left 14 tracks on 11 road segments (avg: 4.2 tracks $/ \mathrm{km}$ ) and 84 and 66 tracks on 18 and 15 forest segments (avg: 15.6 and 14.7 tracks $/ \mathrm{km}$ at 800 and $1000 \mathrm{~m}$ intervals respectively) and both road-forest comparisons showed significant differences $\left(\mathrm{T}_{\mathrm{s}}=-2.9\right.$ and -3.3 respectively, $\left.p<0.01\right)$. At the $400 \mathrm{~m}$ scale, martens left 25 tracks on 14 road segments (avg: 4.5 tracks $/ \mathrm{km}$ ), and 89 and 80 tracks on 18 and 15 forest segments (avg: 12.4 and 13.3 tracks/km at 800 and $1000 \mathrm{~m}$ intervals respectively), although only the latter comparison (ie 400 $\mathrm{m}$ at $1000 \mathrm{~m}$ interval) was significant $\left(\mathrm{T}_{\mathrm{s}}=-2.9, p<0.01\right)$.

\section{Discussion}

This study revealed that martens were as likely to be detected near roads as away from roads. In many Crown Land areas in northern Ontario, secondary roads are developed for logging purposes and hence, residential development is limited and road densities are relatively low. Trappers and wildlife biologists commonly restrict sampling to roadsides because of difficult access to the forest core. Our results show that marten tracks can be found near roads (at least in the first $300 \mathrm{~m}$ ) and thus support the use of road transects for detection surveys (sensu Zielinski and Kucera 1995).

The analysis of track density, on the other hand, showed that tracks were relatively more clumped within forest segments, which suggests different marten movement patterns, and therefore different habitat use by martens near roads. Martens are solitary and territorial (Strickland and Douglas 1987); hence, more tracks in the forest interior is more likely an indication that martens were more active away from than near roads than it is an indication of the presence of more individuals in the forest segments. Vegetation characteristics were apparently not related to this pattern, but results indicated that the number of black spruce was lower near roads. In the study area, black spruce proliferated mostly in mesic environments, and roads likely were set on higher and drier areas or near harvestable stands. Hence, shorter forest stands in 300/800 m segments were likely lowlands and bogs between established roads.

Martens may have been less active near roads because of sub-optimal black spruce cover, but more likely traffic. The observed response of martens the specific 
difference in habitat noted here cannot be imputable to, as some studies sugge:ted that martens will select for a variety of conifer assemblages (D'Eon and Watt 1934). Also, movement patterns of martens may be different in areas of higher road/trffic densities (Reijnen et al. 1997). This must be considered, especially when a measure of habitat use is sought.

The spatial analysis indicated little statistical variation in marten detectabiity, clumping of tracks and vegetation attributes, with a 100-m scale change. Herce, detectability of martens and vegetation characterization were not sensitive to a $100-\mathrm{m}$ scale variation, which suggests that this level of resolution is insignificant relative to marten home ranges sizes (Buskirk and McDonald 1989). On the other hand, it has been suggested that transects used for marten habitat studies be $1 \mathrm{~km}$ or more (Thompson et al. 1989). However, in order to reveal the possible effect of roads on of marten movements, a relatively short distance was chosen at a sale where possibly a given marten would detect, and respond to, the proximity of rads within its home range. Hence, this study examined the response of martens to road at a stand-scale level rather than at the landscape level.

Acknowledgements: Financial support for this study was provided by Northeastern Science and Technology, Ontario Ministry of Natural Resources, and we thank the District office of the ONNR, Timmins, for logistic support and technical avise. We also thank winter and summer field crews, namely S. and L. Beaudin, J. Bisson, D. Briand, P. Cavanagh, C. Chénard, R. Edmunds, G. Finnik, D. Furber, M. Hall, T. Hillis, E. Kresin, B. McCord, B. Olivier Jr., D. Rochon, S. Spencer, L. Tremolay, and J. Trivers for their enthusiastic contribution. This manuscript benefited from the thougitful comments of G. Proulx, E. Cobb, and R.G. Routledge. Figure 1 was prepared by L. L. Larivière rom the Department of Geography, Laurentian University.

\section{References}

Buskirk S. W. and Powell R. A. 1994. Habitat ecology of fishers and martens. [In: Martens, Sablesand Fishers: Biology and Conservation. S. W. Buskirk, A. S. Harestad, M. G. Raphael and R. A. Povell, eds]. Cornell University Press, Ithaca: 283-296.

Buskirk S. W. and McDonald L. L. 1989. Analysis of variability in the home-range size of the Ameican marten. The Journal of Wildlife Management 53: 997-1004.

D'Eon R. G. and Watt W. R. 1994. A forest habitat suitability matrix for northeastern Ontario. Northeast Science and Technology, Ministry of Natural Resources. Report no. TM-004: 1- 83 .

Darveau M., Bélanger L., Huot J., Mélançon E. and De Bellefeuille S. 1997. Forestry practices anc the risk of bird nest predation in a boreal coniferous forest. Ecological Applications 7: 572-580.

García F. J., Díaz M., de Alba J. M., Alonso C. L., Carbonell R., de Carrión M. L., Monedero C.and Santos T. 1998. Edge effects and patterns of winter abundance of wood mice Apodemus sylvaicus in Spanish fragmented forests. Acta Theriologica 43: 255-262.

Gardner J. L. 1998. Experimental evidence for edge-related predation in a fragmented agriculural landscape. Australian Journal of Ecology 23: 311-321.

Grenier Y. and Du Sablon M. 1993. Comparaison entre des prismes de différents facteurs de suface terrière pour établir la structure des diamètres d'un peuplement inéquienne. Forestry Chroicle 69: 193-197.

Hansson L. 1998. Local hot spots and their edge effect: small mammals in oak-hazel woodland. Gikos 81: 55-62.

Jokimäki J. and Huhta E. 1996. Effects of landscape matrix and habitat structure on a bird community in northern Finland: a multi-scale approach. Ornis Fennica 73: 97-113. 
Kuitunen M., Rossi E. and Stenroos A. 1998. Do highways influence density of land birds? Environmental Management 22: 297-302.

Nieni G. J., Hanowski J. M., Lima A. R., Nicholls T. and Weiland N. 1997. A critical analysis on the use of indicator species in management. The Journal of Wildlife Management 61: 1240-1252.

Potvin F. and Breton L. 1997. Short-term effects of clearcutting on martens and their prey in the boreal forest of western Quebec. [In: Martes: taxonomy, ecology, techniques and management. G. Proulx, H. N. Bryant and P. M. Woodard, eds]. The Provincial Museum of Alberta, Edmonton: $452-474$.

Reijnen R., Foppen R. and Veenbaas G. 1997. Disturbance by traffic of breeding birds: evaluation of the effect and considerations in planning and managing road corridors. Biodiversity and Conservation 6 : $567-581$.

SAS 1995. JMP statistics and graphics guide, version 3. SAS Institute Inc., Cary: 1-593.

Stevens S. M. and Husband T. P. 1998. The influence of edge on small mammals: evidence from Brazilian Atlantic forest fragments. Biological Conservation 85: 1-8.

Strickland M. A. and Douglas C. W. 1987. Marten. [In: Wildfurbearer management and conservation in north America. M. Novak, J. A. Baker, M. E. Obbard and B. Malloch, eds]. Ontario Ministry of Natural Resources, Toronto: 548-573.

Thompson I. D., Davidson I. J., O’Donnell S. and Brazeau F. 1989. Use of track transects to measure the relative occurrence of some boreal mammals in uncut forest and regeneration stands. Canadian dournal of Zoology 67: 1816-1823.

Wat: W. R., Baker J. A., Hogg D. M., McNicol J. G. and Naylor B. J. 1996. Forest management guidelines for the provision of marten habitat. Ontario Ministry of Natural Resources 1-26.

Zielinski W. J. and Kucera T. E. 1995. American marten, fisher, lynx, and wolverine: survey methods for their detection. United States Forestry Service, Berkeley, California Report no. PSW-GTR-157: [-163.

Recived 27 January 1999, accepted 2 August 1999. 